\title{
Cav3.2 calcium channels involvement in inflammation and related pain-like symptoms in murine inflammatory models
}

Elodie Picard ${ }^{1}$, Nicolas Kerckhove ${ }^{1}$, Amaury François ${ }^{2}$, Ludivine Boudieu ${ }^{1}$, Elisabeth Billard $^{3}$, Frederic Carvalho ${ }^{1}$, Gemma Bogard ${ }^{4}$, Philippe Gosset ${ }^{4}$, Justine Bourdier ${ }^{1}$, Youssef Aissouni ${ }^{1}$, Emmanuel Bourinet ${ }^{2}$, Alain Eschalier ${ }^{5}$, Laurence Daulhac ${ }^{1}$, and Christophe Mallet $^{1}$

${ }^{1}$ Université Clermont Auvergne

${ }^{2}$ Institut de Genomique Fonctionnelle

${ }^{3}$ Universite Clermont Auvergne

${ }^{4}$ University of Lille

${ }^{5}$ Universite Clermont Auvergne Faculte de Pharmacie

November 14, 2021

\begin{abstract}
Background and Purpose T-type calcium channels, mainly the Cav3.2 subtype, are important contributors to the nociceptive signaling pathway. We investigated their involvement in inflammation and related pain-like symptoms. Experimental Approach The involvement of Cav3.2 and T-type channels was investigated using genetic and pharmacological inhibition to assess mechanical allodynia/hyperalgesia and edema development in two murine inflammatory pain models. The location of Cav3.2 involved in pain-like symptoms was studied in mice with Cav3.2 knocked out in C-low threshold mechanoreceptors (C-LTMR) and the use of ABT-639, a peripherally restricted T-type channel inhibitor. The anti-edematous effect of Cav3.2 inhibition was investigated in chimeric mice with immune cells deleted for Cav3.2. Lymphocytes and macrophages from either green fluorescent protein-targeted Cav3.2 or KO mice were used to determine the expression of Cav3.2 protein and the functional status of the cells. Key Results We showed the role of Cav3.2 channels in the development of pain-like symptoms and edema in the two murine inflammatory pain models. For the first time, we provide evidence of the involvement of Cav3.2 channels located on C-LTMRs in inflammatory pain at both peripheral and primary afferent terminals at the spinal level. We showed that Cav3.2 channels located in $\mathrm{T}$ cells and macrophages contribute to the inflammatory process. Conclusion and Implications This work highlights the crucial role of Cav3.2 channels in inflammation and related pain and suggests that targeting Cav3.2 channels with pharmacological agents could be an attractive and readily evaluable strategy in a clinical trial to relieve chronic inflammatory pain in affected patients.
\end{abstract}

\section{$\mathrm{Ca}_{\mathrm{v}} 3.2$ calcium channels involvement in inflammation and related pain-like symptoms in murine inflammatory models}

Elodie Picard $(\mathrm{PhD})^{1,2,6+}$, Nicolas Kerckhove $(\mathrm{PhD})^{1,2,5+}$, Amaury François $(\mathrm{PhD})^{3}$, Ludivine Boudieu $(\mathrm{PhD})^{1,2}$, Elisabeth Billard $(\mathrm{PhD})^{4}$, Frédéric Antonio Carvalho $(\mathrm{PhD})^{1,2}$, Gemma Bogard $(\mathrm{PhD} \text { student })^{6}$, Philippe Gosset $(\mathrm{PhD})^{6}$, Justine Bourdier $(\mathrm{BSc})^{1,2}$, Youssef Aissouni $(\mathrm{PhD})^{1,2}$, Emmanuel Bourinet $(\mathrm{PhD})^{3}$, Alain Eschalier $(\mathrm{MD}, \mathrm{PhD})^{1,2}$, Laurence Daulhac $(\mathrm{PhD})^{1,2}$, Christophe Mallet $(\mathrm{PhD})^{1,2^{*}}$

${ }^{1}$ Université Clermont Auvergne, Inserm, U1107 Neuro-Dol, Pharmacologie Fondamentale et Clinique de la Douleur, Clermont-Ferrand, France.

2 ANALGESIA Institute, Faculty of Medicine, Clermont-Ferrand, France. 
${ }^{3}$ IGF, Université de Montpellier, CNRS, INSERM, Montpellier, France.

${ }^{4}$ Université Clermont Auvergne, Inserm U1071, INRA USC2018, M2iSH, Clermont-Ferrand, France.

${ }^{5}$ University Hospital of Clermont-Ferrand, Medical Pharmacology Department, Clermont-Ferrand, France.

6 University of Lille, Inserm, U1019, CNRS UMR 9017, CHU Lille, Institut Pasteur de Lille, Center for Infection and Immunity of Lille, Lille, France

+ Drs Picard and Kerckhove contributed equally to the work.

Correspondence : Christophe Mallet, Inserm, Universite Clermont Auvergne, U1107 NeuroDol, Pharmacologie Fondamentale et Clinique de la Douleur, F-63000 Clermont-Ferrand, France; christophe.mallet@uca.fr; Phone: + 33473178103.

Running title: Role of $\mathrm{Ca}_{\mathrm{v}} 3.2$ calcium channels in inflammation and related pain

Keywords: T-type calcium channels; inflammatory pain; inflammation; mechanical hypersensitivity; pharmacology

Funding: This work was supported by Agence Nationale de la Recherche (ANR-15-CE16-0012-01, LABEX ICST, "Investissements d'Avenir" program I-Site CAP 20-25), FRM (equipe FRM 2015) grants and Inserm, CNRS, Clermont Auvergne and Montpellier Universities. Nicolas Kerckhove was supported by fellowships from the European Fund for Regional Economic Development (FEDER), the regional council of AuvergneRhone-Alpes ("Pack Ambition Recherche 2021") and the "Societe Francaise d'Etude et de Traitement de la Douleur" (SFETD).

Data Availability Statement

Data available on request from the authors.

\section{Conflict of Interest}

The authors declare that they have no conflict of interest.

\section{ACKNOWLEDGEMENTS}

The authors thank Christelle Blavignac, Claire Szczepaniak and Lorraine Novais-Gameiro at the "Centre d'Imagerie Cellulaire Sante" (Clermont-Auvergne University) for their technical support for flow cytometry and Pr Serge Alziari of the "Reparation du Genome Mitochondrial" research team (Clermont Auvergne University, France) for his technical support for the generation of chimeric mice.

\section{AUTHOR CONTRIBUTION}

All authors discussed the results and revised or commented on the manuscript.

\section{Study conception and design}

Eschalier, Mallet, Picard, Kerckhove, Bourinet, Daulhac.

\section{Acquisition of data}

Picard, Kerckhove, Billard, Boudieu, Bourinet, Francois, Bourdier, Aissouni, Carvalho, Bogard.

\section{Analysis and interpretation of data}

Picard, Kerckhove, Francois, Boudieu, Billard, Carvalho, Bourdier, Francois, Gosset, Aissouni, Bourinet, Eschalier, Daulhac, Mallet.

\section{ABSTRACT \\ Background and Purpose}


T-type calcium channels, mainly the $\mathrm{Ca}_{\mathrm{v}} 3.2$ subtype, are important contributors to the nociceptive signaling pathway. We investigated their involvement in inflammation and related pain-like symptoms.

\section{Experimental Approach}

The involvement of $\mathrm{Ca}_{\mathrm{v}} 3.2$ and T-type channels was investigated using genetic and pharmacological inhibition to assess mechanical allodynia/hyperalgesia and edema development in two murine inflammatory pain models. The location of $\mathrm{Ca}_{\mathrm{v}} 3.2$ involved in pain-like symptoms was studied in mice with $\mathrm{Ca}_{\mathrm{v}} 3.2$ knocked out in C-low threshold mechanoreceptors (C-LTMR) and the use of ABT-639, a peripherally restricted T-type channel inhibitor. The anti-edematous effect of $\mathrm{Ca}_{\mathrm{v}} 3.2$ inhibition was investigated in chimeric mice with immune cells deleted for $\mathrm{Ca}_{\mathrm{v}} 3.2$. Lymphocytes and macrophages from either green fluorescent protein-targeted $\mathrm{Ca}_{\mathrm{v}} 3.2$ or $\mathrm{KO}$ mice were used to determine the expression of $\mathrm{Ca}_{\mathrm{v}} 3.2$ protein and the functional status of the cells.

\section{Key Results}

We showed the role of $\mathrm{Ca}_{\mathrm{v}} 3.2$ channels in the development of pain-like symptoms and edema in the two murine inflammatory pain models. For the first time, we provide evidence of the involvement of $\mathrm{Ca}_{\mathrm{v}} 3.2$ channels located on C-LTMRs in inflammatory pain at both peripheral and primary afferent terminals at the spinal level. We showed that $\mathrm{Ca}_{\mathrm{v}} 3.2$ channels located in $\mathrm{T}$ cells and macrophages contribute to the inflammatory process.

\section{Conclusion and Implications}

This work highlights the crucial role of $\mathrm{Ca}_{\mathrm{v}} 3.2$ channels in inflammation and related pain and suggests that targeting $\mathrm{Ca}_{\mathrm{v}} 3.2$ channels with pharmacological agents could be an attractive and readily evaluable strategy in a clinical trial to relieve chronic inflammatory pain in affected patients.

Keywords: inflammatory pain, rheumatoid arthritis (RA), T-type calcium channels.

\section{INTRODUCTION}

Pain is the most challenging symptom for patients suffering from chronic inflammatory diseases (Taylor et al., 2010; Walsh and McWilliams, 2014). It is commonly encountered in osteoarthritis, rheumatoid arthritis, psoriasis, contact dermatitis, interstitial cystitis, and host defense or inflammatory bowel disease(PinhoRibeiro et al., 2017) and is a major challenge for clinicians(da Silva et al., 2010). Pain impairs patient quality of life and therefore has a major impact on both their physical and mental well-being (Walsh and McWilliams, 2014; Sturgeon et al., 2016). Pharmacological treatments (Smolen et al., 2017) to improve rheumatoid arthritis (RA) or RA-related pain include paracetamol, opioids, nonsteroidal anti-inflammatory drugs (NSAIDs) and biologic agents, such as anti-tumor necrosis factor (anti-TNF). However, treatments are not consistently effective and/or are associated with strong adverse effects (Hojsted and Sjogren, 2007; Graham et al., 2013; Ioannidis et al., 2013; Boyman et al., 2014; Roda et al., 2016), as evidenced by the current opioid use crisis in North America. More importantly, pain can still be problematic despite optimal control of the inflammatory disease (Taylor et al., 2010; Walsh and McWilliams, 2014; Smolen et al., 2016). Thus, there is considerable interest in finding new strategies to develop effective analgesics to relieve chronic inflammatory-related pain.

Previous studies reported that activation of T-type voltage-gated calcium channels contributes to the nociceptive signaling pathway and showed that these channels are involved in the pathophysiology of pain (Perez-Reyes, 2003; Todorovic and Jevtovic-Todorovic, 2011; Bourinet et al., 2016; Snutch and Zamponi, 2018). T-type calcium channels play an important role in cell excitability and calcium signaling, contributing to a wide variety of physiological functions or pathological situations. In the nervous system, these channels are involved in spontaneous discharges, deep sleep, epilepsy and perception of pain (Perez-Reyes, 2003; Lee et al., 2004; Choi et al., 2007). They belong to a family composed of $\mathrm{Ca}_{\mathrm{v}} 3.1, \mathrm{Ca}_{\mathrm{v}} 3.2$ and $\mathrm{Ca}_{\mathrm{v}} 3.3$, of which the $\mathrm{Ca}_{\mathrm{v}} 3.2$ subtype is reported to have a major pronociceptive function (Bourinet et al., 2005; Choi et al., 2007; Todorovic and Jevtovic-Todorovic, 2011; Jacus et al., 2012; Snutch and Zamponi, 2018). Several studies 
using different chronic pain animal models showed that inhibition of $\mathrm{Ca}_{\mathrm{v}} 3.2$ channels strongly reduced neuropathic pain (For review, see Bourinet et al., 2016), inflammatory pain (Kerckhove et al., 2019) and visceral pain (Francois et al., 2013; Scanzi et al., 2016). The role of $\mathrm{Ca}_{\mathrm{v}} 3.2$ channels in somatic inflammatory chronic pain has been poorly studied and published results are inconsistent: inhibition of $\mathrm{Ca}_{\mathrm{v}} 3.2$ channels either showed (Choi et al., 2007; Kerckhove et al., 2014) or failed to show (Berger et al., 2014; Garcia-Caballero et al., 2014; Smith et al., 2017) an anti-hyperalgesic effect.

The aim of the present study was to clarify the involvement of T-type calcium channels, mainly the $\mathrm{Ca}_{\mathrm{v}} 3.2$ member, in this inflammatory context. Using both genetic and pharmacological strategies in two murine models of subacute and maintained articular inflammation, we confirmed the role of $\mathrm{Ca}_{\mathrm{v}} 3.2$ channels in inflammation and inflammatory-related pain. Our study supports the possibility of considering inhibition of $\mathrm{Ca}_{\mathrm{v}} 3.2$ channels as a new therapeutic perspective in the treatment of inflammation and related pain.

\section{MATERIALS AND METHODS}

\section{Animals}

All experiments were performed in accordance with the ethical guidelines set out by the International Association for the Study of Pain and the relevant European legislation (Directive 2010/63/EU) and given approval by the local ethics committee (CEMEA Auvergne; reference 6295). Eight-week-old male C57BL/6j mice were purchased from Janvier Laboratories (Le Genest-Saint-Isle, France). Cav 3.2 knock-out ( $\left.\mathrm{Ca}_{\mathrm{v}} 3.2 \mathrm{KO}\right)$ male mice, originally generated by Chen et al. (2003), and their wild type (WT) littermates were bred in the animal facility of Clermont-Auvergne University. We also used $\mathrm{Ca}_{\mathrm{v}} 3.2$-GFP-flox knock-in $\left(\mathrm{Ca}_{\mathrm{v}} 3.2^{\mathrm{GFP}-f l o x} \mathrm{KI}\right)$ mice, generated by Francois et al. (2015). A conditional $\mathrm{Ca}_{\mathrm{v}} 3.2 \mathrm{KO}$ mouse in C-LTMRs was generated by crossing the $\mathrm{Ca}_{\mathrm{v}} 3.2^{\text {GFP-flox }} \mathrm{KI}$ mice with $\mathrm{Na}_{\mathrm{v}} 1.8^{\text {cre }}$ KI mice (Stirling et al., 2005; Francois et al., 2015). The resulting mice were designated $\mathrm{Ca}_{\mathrm{v}} 3.2^{\mathrm{Nav} 1.8} \mathrm{cKO}$, their control littermates $\left(\mathrm{Ca}_{\mathrm{v}} 3.2^{\text {GFP-flox }} \mathrm{KI}\right.$ mice) were also used. Chimeric mice were generated to determine the role in inflammation of $\mathrm{Ca}_{\mathrm{v}} 3.2$ located in immune versus neuronal cells. All animals were housed under standard laboratory conditions (12-hour light/dark cycle, temperature of 21 to $22 \mathrm{degC}, 55 \%$ humidity under specific pathogen free conditions). Food and water were availablead libitum. They were acclimatized for a week before testing.

\section{Murine models of inflammatory pain and clinical evaluation}

The carrageenan model was induced by an intraplantar subcutaneous injection of $20 \mu \mathrm{L}$ of $3 \% \lambda$-carrageenan (Dalmann et al., 2015). The monoarthritic model was induced by injection of $5 \mu \mathrm{l}$ of Complete Freund's Adjuvant (CFA) on either side of the left ankle joint of mice under brief anesthesia (2.5\% isoflurane inhalation) (Kerckhove et al., 2014).

To test mechanical allodynia and hyperalgesia, two calibrated von Frey filaments producing a force of 0.04 $\mathrm{g}$ and $1.4 \mathrm{~g}$ (Bioseb, France) were used, respectively, as described previously (Dalmann et al., 2015). The number of paw withdrawal responses to five stimulations for a given filament force was counted and used as a "pain" parameter (VF score).

The size of the paw edema was measured with a caliper. For the assessment of interleukine-6 (IL-6) content, the paw edema was removed and incubated in RPMI (Roswell Park Memorial Institute medium, Sigma Aldrich, Saint Louis, USA) supplemented with 10\% antibiotic cocktail (penicillin, streptomycin, \#P11-010, PAA, Austria) at $37^{\circ} \mathrm{C}$ under a $5 \% \mathrm{CO}_{2}$ atmosphere. After overnight incubation, IL-6 was quantified in the supernatant by ELISA.

\section{Bone-marrow derived macrophages and lymphocytes $\mathrm{T} \mathrm{CD4}{ }^{+}$cells}

Bone-marrow derived macrophages (BMDM) and $\mathrm{CD} 4^{+} \mathrm{T}$ cells were prepared from $\mathrm{WT}$ and $\mathrm{Ca}_{\mathrm{v}} 3.2^{\mathrm{GFP}-\text { flox }}$ $\mathrm{KI}$ mice and used to investigate the expression of $\mathrm{Ca}_{\mathrm{v}} 3.2$ channels by immunohistochemistry labelling. BMDM from WT and $\mathrm{Ca}_{\mathrm{v}} 3.2 \mathrm{KO}$ mice was used to investigate the impact of $\mathrm{Ca}_{\mathrm{v}} 3.2$ deletion on LPS-induced morphological modification, IL-6 secretion and intracellular calcium by immunofluorescent labelling, ELISA, 
and calcium imaging. $\mathrm{CD}^{+} \mathrm{T}$ cells from $\mathrm{WT}$ and $\mathrm{Ca}_{\mathrm{v}} 3.2 \mathrm{KO}$ mice were used to assess the proliferation capacities after CD3/CD28 activation by flow cytometry.

\section{Drugs}

$\lambda$-carrageenan was purchased from Sigma-Aldrich, France. CFA consisted ofMycobacterium butyricum (Difco Laboratories, Detroit, USA) dissolved in paraffin oil and saline $(0.9 \% \mathrm{NaCl})$. The solution was autoclaved for 20 min at $120^{\circ} \mathrm{C}$. TTA-A2 (Alomone labs, Jerusalem, Israel) was dissolved in DMSO/Tween80/saline (1:1:8) and orally administered at $1 \mathrm{mg} / \mathrm{kg}(10 \mathrm{ml} / \mathrm{kg})$. ABT-639 was purchased from CliniSciences (Nanterre, France), dissolved in DMSO/saline (1:9) and injected either intraperitoneally $(10,30,100 \mathrm{mg} / \mathrm{kg}, 10 \mathrm{ml} / \mathrm{kg})$ or subcutaneously in the hind paw $(2.5 \mu \mathrm{g}$ in $20 \mu \mathrm{l})$ or intrathecally $(10 \mu \mathrm{g}$ in $5 \mu \mathrm{l})$.

\section{Experimental protocol}

The design, analysis and reporting of the research were carried out according to the ARRIVE guidelines (Percie du Sert et al., 2020). The animals were randomly divided into 6-10 mice per group. Randomized treatments were administered according to the method of equal blocks to assess simultaneously the effect of the different treatments and to avoid unverifiable and time-variable environmental influences. All experiments were performed in a quiet room by the same blinded experimenter.

\section{Statistical analysis}

The data and statistical analysis comply with recommendations for experimental design and analysis in pharmacology (Curtis et al., 2015, 2018). Statistical analysis was performed with Prism 7 software (GraphPad Prism, La Jolla, USA). All data are expressed as the mean \pm standard error of the mean (SEM). We used a two-way (time and pharmacological treatment or time and genotype) analysis of variance (ANOVA) followed by the Bonferroni post-hoc test for multiple comparisons. For other analyses, we used a Mann-Whitney test. Data were considered statistically significant when $p$ was $<0.05$.

\section{Additional materials and methods}

Reagents and more detailed methods for murine models of inflammatory pain and clinical evaluation, generation of chimeric mice, immunohistochemistry, flow cytometry analysis and ELISA are described in the Supplementary Materials and Methods .

\section{RESULTS}

Involvement of T-type channels in the development of inflammation and related mechanical hypersensitivity: pharmacological evidence

First, we investigated the effect of inhibiting T-type channels inhibition with TTA-A2 a pharmacological blocker with a great selectivity for T-type channels on inflammation and related pain in two murine models of inflammation: the carrageenan and CFA models. In the carrageenan model, vehicle treated mice had significantly increased responses to the von Frey test, thereby demonstrating the presence of a mechanical allodynia (Figure 1A left ), hyperalgesia (Figure 1B left ) and edema (Figure 1C left ). TTA-A2 (1 $\mathrm{mg} / \mathrm{kg}$, p.o. ) quickly and strongly suppressed nociceptive behavior for a period of 1-2 hours (Figures 1A left and 1B left ) and reduced edema size (Figure 1C left ). Similarly, in the CFA model seven day after the model induction, acute treatment with TTA-A2 $(1 \mathrm{mg} / \mathrm{kg}$, p.o. $)$, resulted in a transient analgesic effect similar to that observed in the carrageenan model (Figures 1A middle and 1B middle ). However, no effect on edema size was observed (Figure 1C middle ). In contrast, chronic TTA-A2 administration (1 $\mathrm{mg} / \mathrm{kg}$, p.o. ) for one week after CFA model induction (day 7 to 14) resulted in a progressive analgesic effect reaching significance after 5 days (from day 11 to 14 post CFA). Moreover the analgesic effect was long lasting, as indicated by the daily pain threshold measured 6 hours after the TTA treatment, a time point exceeding the duration of TTA acute effect (Figures 1A right and 1B right ). Unlike to the acute TTAA2 treatment, chronic treatment significantly reduced edema size, with the same kinetics as that obtained for the analgesic effect (Figure 1C right ). Moreover, IL-6 levels in edemas at D14 were lower in TTA-A2 treated mice than in the VEH control (VEH: $4209.65 \pm 166.58 \mathrm{pg} / \mathrm{ml}$ vs TTA-A2: $1719.20 \pm 133.2 \mathrm{pg} / \mathrm{ml}$, 
$p=0.0019$, Mann Whitney test). Taken together, these pharmacological data provide supporting evidence toward an involvement of T-type channels in inflammation and related pain.

Involvement of $\mathrm{Ca}_{\mathrm{v}} 3.2$ channels in the development of inflammation and related mechanical hypersensitivity: genetic evidence

Taking into consideration that no pharmacological tool is exclusively specific to $\mathrm{Ca}_{\mathrm{v}} 3.2$ channels, we investigated the contribution of these channels in inflammation and related allodynia/hyperalgesia using mice constitutively deleted of the CACNA1H gene $\left(\mathrm{Ca}_{\mathrm{v}} 3.2 \mathrm{KO}\right)$. In the carrageenan model, $\mathrm{Ca}_{\mathrm{v}} 3.2 \mathrm{KO}$ mice did not develop allodynia (Figure 2A left ) nor hyperalgesia (Figure 2B left ) compared to their control wild-type (WT) littermates. Edema development was observed in both $\mathrm{WT}$ and $\mathrm{Ca}_{\mathrm{v}} 3.2 \mathrm{KO}$ mice but to a significantly lesser extent in the latter (Figure $\mathbf{2 C}$ left ). In addition, the pro-inflammatory cytokine IL-6 level in the edema was significantly lower in $\mathrm{Ca}_{\mathrm{v}} 3.2 \mathrm{KO}$ mice (Figure 2D left ). In the CFA model, similar results were obtained: a lack of mechanical nociceptive behavior in $\mathrm{Ca}_{\mathrm{v}} 3.2 \mathrm{KO}$ mice (Figures $\mathbf{2 A}$ right and 2B right ) and a significant decrease in both edema size (Figure 2C right ) and IL-6 level in the edema (Figure 2D right ) compared to those in WT animals. Thus, these findings underscore the importance of $\mathrm{Ca}_{\mathrm{v}} 3.2$ subtype channels in inflammation and related allodynia/hyperalgesia.

\section{Functional location of $\mathrm{Ca}_{\mathrm{v}} 3.2$ channels involved in inflammatory pain-like symptoms}

Next, we gained further insights into the role of $\mathrm{Ca}_{\mathrm{v}} 3.2$ channels in inflammatory pain by investigating the impact of their inhibition at different locations. We assessed the effect of the deletion of $\mathrm{Ca}_{\mathrm{v}} 3.2$ channels located in a population of primary sensory neurons in mice, named C-LTMRs. These fibers express both the sodium channel $\mathrm{Na}_{\mathrm{v}} 1.8$ and the calcium channel $\mathrm{Ca}_{\mathrm{v}} 3.2$ (François et al., 2015) and have been shown to contribute to inflammatory pathological pain (Seal et al., 2009; Delfini et al., 2013; François et al., 2015; Reynders et al., 2015; Urien et al., 2017; Bohic et al., 2020). We therefore used a genetic mouse model in which the expression of $\mathrm{Ca}_{\mathrm{v}} 3.2$ channels is conditionally knocked out in C-LTMRs, by crossing $\mathrm{Ca}_{\mathrm{v}} 3.2^{\mathrm{GFP}-f l o x} \mathrm{KI}$ with $\mathrm{Na}_{\mathrm{v}} 1.8^{\text {cre }} \mathrm{KI}$ mice as previously described (François et al., 2015). In this mouse model $\left(\mathrm{Ca}_{\mathrm{v}} 3.2^{\mathrm{Nav1}} .8 \mathrm{cKO}\right)$, a significant decrease in allodynia and hyperalgesia in the von Frey test was observed after carrageenan (Figure 3A ) or CFA (Figures 3B ) injections compared to control $\mathrm{Ca}_{\mathrm{v}} 3.2^{\mathrm{GFP}-f l o x}$ KI littermates. These results evidenced that the $\mathrm{Ca}_{\mathrm{v}} 3.2$ channels located on C-LTMRs are required for the development of inflammatory allodynia/hyperalgesia. This involvement of C-LTMRs-located $\mathrm{Ca}_{\mathrm{v}} 3.2$ channels could arise from their projection in the spinal cord (pre-synaptic $\mathrm{Ca}_{\mathrm{v}} 3.2$ channels) or their origin in peripheral tissue $\left(\mathrm{Ca}_{\mathrm{v}} 3.2\right.$ channels on primary afferent fibers). Therefore, the contribution of both locations was studied. First, peripheral $\mathrm{Ca}_{\mathrm{v}} 3.2$ channels involvement was evaluated using an intraperitoneal injection of ABT-639 $(10,30$ and $100 \mathrm{mg} / \mathrm{kg})$, a peripherally restricted T-type calcium channels inhibitor. After such treatment, we observed a robust analgesic effect on allodynia and hyperalgesia at the two highest doses tested (30 and $100 \mathrm{mg} / \mathrm{kg}$ ) in both carrageenan (Figure 4A ) and CFA (Figure 4B ) models. This result was confirmed by performing an intraplantar injection of ABT-639 (2.5 $\mu \mathrm{g} /$ mouse in $20 \mu \mathrm{l})$ in the CFA model (Figure 4C ). Second, an intrathecal injection of ABT-639 (10 $\mu \mathrm{g} /$ mouse in $5 \mu \mathrm{l})$ was performed in the CFA model to determine the contribution of $\mathrm{Ca}_{\mathrm{v}} 3.2$ channels in primary afferent spinal terminals to allodynia/hyperalgesia. The injection partially reduced the responses to the von Frey test (Figure 4D ). Thus, both pharmacological and genetic tools identified the involvement in inflammatory pain of $\mathrm{Ca}_{\mathrm{v}} 3.2$ located in primary afferent neurons at both the peripheral and spinal terminals.

\section{Involvement of immune cells in the anti-inflammatory action of $\mathrm{Ca}_{\mathrm{v}} 3.2$ channels inhibition}

We then studied the mechanisms underlying the involvement of $\mathrm{Ca}_{\mathrm{v}} 3.2$ channels in edema development. One possible explanation for the decreased edema observed in mice after $\mathrm{Ca}_{\mathrm{v}} 3.2$ channel inhibition was a reduction of the neurogenic inflammation process (Xanthos and Sandkühler, 2014). Indeed, inhibition of $\mathrm{Ca}_{\mathrm{v}} 3.2$ located in C-LTMRs could reduce the release of peripheral pro-inflammatory neuropeptides in response to antidromic nerve stimulation. To test this hypothesis, we assessed edema development in $\mathrm{Ca}_{\mathrm{v}} 3.2^{\mathrm{Nav} 1.8}$ cKO mice. No significant difference was observed in edema volume between $\mathrm{Ca}_{\mathrm{v}} 3.2^{\mathrm{Nav} 1.8} \mathrm{cKO}$ mice and their control $\mathrm{Ca}_{\mathrm{v}} 3.2^{\mathrm{GFP}-f l o x} \mathrm{KI}$ littermates after carrageenan injection (Figure 5A ) thereby excluding the hypothesis 
of the neuronal nature of the anti-edematous effect of $\mathrm{Ca}_{\mathrm{v}} 3.2$ channel inhibition at least originating from C-LTMR afferents. The other explanation was based on the involvement of $\mathrm{Ca}_{\mathrm{v}} 3.2$ channels expressed in immune cells in edema formation. To test this, we designed chimeric mice with genetic deletion of $\mathrm{Ca}_{\mathrm{v}} 3.2$ only in hematopoietic cells (progenitor of immune cells) or only in non-hematopoietic cells (Figure 5B ). The absence of $\mathrm{Ca}_{\mathrm{v}} 3.2$ channels specifically in the immune system (WT recipient mice transplanted with $\mathrm{KO}$ immune cells) reduced edema development, as in constitutive $\mathrm{Ca}_{\mathrm{v}} 3.2 \mathrm{KO}$ mice (KO recipient mice transplanted with $\mathrm{KO}$ immune cells) (Figure 5C ). In contrast, edemas were restored in $\mathrm{Ca}_{\mathrm{v}} 3.2 \mathrm{KO}$ recipient mice receiving WT hematopoietic cells (Figure 5C ). Consistently, the absence of $\mathrm{Ca}_{\mathrm{v}} 3.2$ channels only in hematopoietic cells significantly reduced the production of IL-6, as in constitutive $\mathrm{Ca}_{\mathrm{v}} 3.2 \mathrm{KO}$ mice (Figure 5D ). Our results showed that $\mathrm{Ca}_{\mathrm{v}} 3.2$ channels expressed in immune cells are strongly involved in edema development and IL-6 production.

To identify the nature of the immune cells involved in $\mathrm{Ca}_{\mathrm{v}} 3.2$-dependent edema development, $\mathrm{Ca}_{\mathrm{v}} 3.2$ channel expression was investigated in macrophages and $\mathrm{T}$ cells. We used $\mathrm{Ca}_{\mathrm{v}} 3.2^{\mathrm{GFP}-\text { flox }} \mathrm{KI}$ mice to detect $\mathrm{Ca}_{\mathrm{v}} 3.2$ channel protein. Thus, bone marrow derived macrophages (BMDM) and CD4 positive $\mathrm{T}$ cells $\left(\mathrm{CD} 4^{+} \mathrm{T}\right.$ cells) were obtained from the femurs and spleen, respectively, of $\mathrm{Ca}_{\mathrm{v}} 3.2^{\text {GFP-flox }} \mathrm{KI}$ mice or control WT mice and were labelled with an anti-eGFP antibody. Immunocytochemistry revealed the expression of $\mathrm{Ca}_{\mathrm{v}} 3.2$ channels in both BMDM and lymphocyte CD4 ${ }^{+} \mathrm{T}$ cells (Figure $5 \mathrm{E}$ ).

\section{Inflammation is modulated by $\mathrm{Ca}_{\mathrm{v}} 3.2$ expressed in macrophages and lymphocytes $\mathrm{T} \mathrm{CD}^{+}$}

The presence of $\mathrm{Ca}_{\mathrm{v}} 3.2$ channels in BMDM and $\mathrm{CD} 4^{+} \mathrm{T}$ cells led us to investigate the impact of these channels on the activation of both types of cells. To demonstrate the role of $\mathrm{Ca}_{\mathrm{v}} 3.2$ channels in BMDM, in vitro studies were performed on BMDM culture of $\mathrm{Ca}_{\mathrm{v}} 3.2 \mathrm{KO}$ and $\mathrm{WT}$ mice. The analysis of BMDM morphology, performed by phalloidin-immunofluorescence labelling of actin, revealed swollen morphology in WT BMDM in presence of LPS (cells area without LPS $=283+-15 \mu \mathrm{m}^{2}$; with LPS $=643 \pm 22 \mu \mathrm{m}^{2}$ ). $\mathrm{Ca}_{\mathrm{v}} 3.2$ KO BMDM had the same basal morphology as WT BMDM but no morphological change was observed after

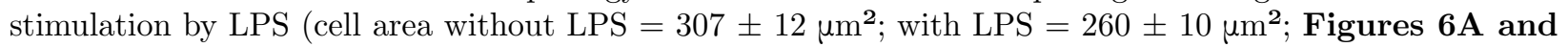
6B left panel ). In addition, $\mathrm{Ca}_{\mathrm{v}} 3.2 \mathrm{KO}$ BMDM produced a smaller amount of IL-6 than WT BMDM in presence of LPS (Figure 6B right panel ). A reduction of TNF- $\alpha$ production was also observed in LPS-stimulated Ca 3.2 KO BMDM (WT: $1,400.56 \pm 193.08$ pg $/ \mathrm{ml}$ vs KO Ca $3.2: 462.22 \pm 196.79$ pg/ml, $p$ $=0.0045$, Mann Whitney test) as compared with levels of unstimulated BMDM (WT: $65.67 \pm 21.19 \mathrm{pg} / \mathrm{ml}$ vs $\mathrm{KO} \mathrm{Ca}$. $3.2: 19.86 \pm 19.39 \mathrm{pg} / \mathrm{ml}$ ). As calcium is a major factor in macrophage activation (Zhou et al., 2006), we thought it would be of interest to investigate variations of intracellular calcium concentration after LPS stimulation. The results showed that $30.2 \pm 5.6 \%$ of WT BMDM cells and only $6.7 \pm 2.1 \%$ of $\mathrm{Ca}_{\mathrm{v}} 3.2$ KO BMDM cells induced elevation of intracellular calcium in response to LPS stimulation (Figure 6C ).

An assessment of the immune cell phenotype was performed by using flow cytometry analysis of total spleen cells from WT and $\mathrm{Ca}_{\mathrm{v}} 3.2 \mathrm{KO}$ mice. The expression of $\mathrm{CD} 86$, which is required for $\mathrm{T}$ cells activation, was used to measure the activation status of antigen-presenting cells (APC) (Hellman and Eriksson, 2007). Median fluorescence intensity in macrophages, $\mathrm{CD} 11 \mathrm{~b}^{+}$dendritic cells and inflammatory monocytes was significantly lower in spleen cells from $\mathrm{Ca}_{\mathrm{v}} 3.2 \mathrm{KO}$ mice than in those of the WT mice (Figure 6D ) whereas the absolute number of these APC were unchanged (data not shown). These results indicate, at the basal level, a defect in APC activation that could alter T-cells activation and thus the immune response. Moreover, we analyzed the proliferation capacities of $\mathrm{WT}$ and $\mathrm{Ca}_{\mathrm{v}} 3.2 \mathrm{KO} \mathrm{CD}^{+} \mathrm{T}$ cells activated ex vivo by CD3/CD28. T-cell proliferation, assessed at day 4, was significantly lower in $\mathrm{Ca}_{\mathrm{v}} 3.2 \mathrm{KO}$ mice than in WT mice $(54.6 \%$ as compared with $91.3 \%$ divided cells, respectively;Figure $\mathbf{6 E}$ ). These findings led to conclude that the absence of $\mathrm{Ca}_{\mathrm{v}} 3.2$ channels in $\mathrm{T}$ cells impaired or delayed their proliferation, which could partly account for the reduced edema size observed in the $\mathrm{Ca}_{\mathrm{v}} 3.2 \mathrm{KO}$ mice.

\section{DISCUSSION}

Using in vivo and ex vivo methods, coupled with genetic and pharmacological strategies, this work highlights the involvement of $\mathrm{Ca}_{\mathrm{v}} 3.2 \mathrm{~T}$-type channels in the development and maintenance of edema and inflammatory 
hypersensitivity, with a requirement of $\mathrm{Ca}_{\mathrm{v}} 3.2$ channels being required in $\mathrm{T} \mathrm{CD} 4^{+}$cells, macrophages and the primary afferent fibers C-LTMRs. From a clinical point of view, these results suggest that T-type calcium channels could be an interesting target for the treatment of inflammatory pain.

We first demonstrated that inhibition of T-type calcium channel by TTA-A2, ABT-639 and Ca 3.2 channels deletion $\left(\mathrm{Ca}_{\mathrm{v}} 3.2 \mathrm{KO}\right.$ mice), reduced mechanical allodynia and hyperalgesia in the carrageenan and CFA models. These results are consistent with those of previous studies using the same models (François et al., 2015; Kerckhove et al., 2019) and in other inflammatory contexts (Choi et al., 2007; Kerckhove et al., 2014). Interestingly, repeated administration of TTA-A2 accounts for a maintained antihyperalgesic/anti-allodynic action. In parallel, we reported for the first time the involvement of $\mathrm{Ca}_{\mathrm{v}} 3.2$ channels in the inflammation process. We observed an anti-inflammatory effect after genetic and pharmacological inhibition of $\mathrm{Ca}_{\mathrm{v}} 3.2$ channels, suggesting a pathophysiological role of these channels not only in pain but also in the inflammatory process. These results are consistent with others showing a contribution of $\mathrm{Ca}_{\mathrm{v}} 3.2$ to the development of bladder inflammation in cyclophosphamide-induced cystitis (Matsunami et al., 2012). In the CFA model, acute administration of TTA-A2 failed to reduce edema size, suggesting that the dose or duration of treatment was not sufficient in a setting of chronic inflammation. In contrast, their repeated administration significantly reduced edema volume throughout the experiment. The genetic and pharmacological inhibition of $\mathrm{Ca}_{\mathrm{v}} 3.2$ channels systematically induced an almost complete reduction of allodynia/hyperalgesia but only partially inhibited edema volume. These results confirm the well documented dissociation between pain and edema (Lee and Jeong, 2002) and suggest a greater involvement of $\mathrm{Ca}_{\mathrm{v}} 3.2$ channels in the pain process than in inflammation which is regulated by numerous various mechanisms.

Given the marked effect of the inhibition of $\mathrm{Ca}_{\mathrm{v}} 3.2$ channels on inflammatory pain, determination of their functional location to modulate this pathophysiological process is of prime interest. C-LTMRs are specialized subpopulations of cutaneous afferents that modulate mechanical and chemical pain hypersensitivity and consist of two third $\mathrm{Ca}_{\mathrm{v}} 3.2$ channels containing primary afferent neurons lumbar DRG in mice (François et al., 2015). We used $\mathrm{Ca}_{\mathrm{v}} 3.2^{\text {Nav1.8 }}$ cKO mice to delete $\mathrm{Ca}_{\mathrm{v}} 3.2$ channels solely in C-LTMRs. Strikingly, this specific tool uncovers that pain-like symptoms were absent in $\mathrm{Ca}_{\mathrm{v}} 3.2^{\mathrm{Nav} 1.8} \mathrm{cKO}$ mice submitted to the two inflammatory model studied, corroborating previous finding on formalin pain (François et al., 2015). The same observation was also reported in neuropathic (François et al., 2015) and visceral (Picard et al., 2019) pain murine models further supporting that $\mathrm{Ca}_{\mathrm{v}} 3.2$ channels in C-LTMR are essential to build up nociceptive symptoms. In the present study, the reduction of pain-like inflammatory symptoms after treatment with systemic, intrathecal or intraplantar administration of ABT-639 indicated that $\mathrm{Ca}_{\mathrm{v}} 3.2$ expressed at multiple subcellular levels from the peripheral to the central terminal are involved in the antihyperalgesic action induced by $\mathrm{Ca}_{\mathrm{v}} 3.2$ inhibition. The study of Jarviset al . (2014) also evidenced the analgesic effect of ABT639 in different murine models of neuropathic pain. However, a clinical trial with ABT-639 in patients with diabetic neuropathy failed to demonstrate any efficacy of the antagonist, whose tolerability was nevertheless good; the low doses used were considered as a possible explanation of this negative result (Ziegler et al., 2015). Clinical evaluations of local intradermal injection of TTA-A2 in a muscle pain model in healthy volunteers and patients (three patients with chronic pain) showed a decrease in mechanical and cold allodynia with no adverse effect (Samour et al., 2015).

In some conditions, inflammation can be controlled by neuronal mediators in a process called neurogenic inflammation (Xanthos and Sandkühler, 2014). To determine the involvement of $\mathrm{Ca}_{\mathrm{v}} 3.2$ channels in this process, two strategies were used. With regard to neuronal $\mathrm{Ca}_{\mathrm{v}} 3.2$ channels, we observed no change in edema size in $\mathrm{Ca}_{\mathrm{v}} 3.2^{\mathrm{Nav} 1.8}$ cKO mice, which strongly suggests that $\mathrm{Ca}_{\mathrm{v}} 3.2$ channels expressed on C-LTMRs are not involved in subacute or maintained inflammation. Experiments using chimeric mice enabled us to demonstrate for the first time that the absence of $\mathrm{Ca}_{\mathrm{v}} 3.2$ channels in hematopoietic cells was sufficient to reduce edema development and pro-inflammatory mediator release. Interestingly, this reduction was close to that observed in constitutive $\mathrm{Ca}_{\mathrm{v}} 3.2 \mathrm{KO}$ mice, suggesting that $\mathrm{Ca}_{\mathrm{v}} 3.2$ channels expressed by hematopoietic cells were involved in the control of inflammation. Accordingly, transplantation of hematopoietic cells expressing $\mathrm{Ca}_{\mathrm{v}} 3.2$ channels into constitutive $\mathrm{Ca}_{\mathrm{v}} 3.2 \mathrm{KO}$ animals completely restored edema development and pro-inflammatory mediator release. Thus, these in vivo experiments provide evidence that inflammation induced by carrageenan 
and CFA involved $\mathrm{Ca}_{\mathrm{v}} 3.2$ channels expressed in hematopoietic cells. We then explored more specifically the potential contribution of BMDM and $\mathrm{CD} 4^{+} \mathrm{T}$ cells, two actors that play a crucial role in the inflammatory diseases (Weyand and Goronzy, 2021). Using immunocytochemistry, we demonstrated, for the first time, that these cells expressed $\mathrm{Ca}_{\mathrm{v}} 3.2$ channel protein consistent with a previous demonstration of low level of $\mathrm{Ca}_{\mathrm{v}} 3.2$ transcript expression in murine CD4 ${ }^{+} \mathrm{T}$ cells (Jarvis et al., 2014). Genetic deletion of $\mathrm{Ca}_{\mathrm{v}} 3.2$ channels in BMDM showed no morphological signs of activation and lower production of pro-inflammatory mediators (IL-6 and TNF- $\alpha$ ) in response to LPS stimulation. This result accounts for the fact that $\mathrm{Ca}_{\mathrm{v}} 3.2$ channels are involved in exocytose not only in excitable cells but also in non-excitable cell (Carbone et al., 2006). This could be related to a reduced calcium recruitment in LPS-stimulated BMDM after $\mathrm{Ca}_{\mathrm{v}} 3.2$ deletion, which lead to a reduced level of pro-inflammatory mediators. A relationship between the calcium signaling pathway and the production of pro-inflammatory mediators has already been established in LPS-stimulated rat peritoneal macrophages (Zhou et al., 2006). $\mathrm{Ca}_{\mathrm{v}} 3.2$ channel deletion was also associated with a lower activation status in spleen APC suggesting an impaired ability of these cells to promote $\mathrm{T}$ cell activation. Moreover, $\mathrm{Ca}_{\mathrm{v}} 3.2$ gene invalidation strongly affected T-cell proliferation upon CD3/CD28 stimulation, suggesting the involvement of $\mathrm{Ca}_{\mathrm{v}} 3.2$ channels in early events of lymphocyte activation. In conclusion, $\mathrm{Ca}_{\mathrm{v}} 3.2$ gene deletion strongly impairs the function of $\mathrm{APC}$ and $\mathrm{CD} 4^{+} \mathrm{T}$ cells, a process that could explain the involvement of $\mathrm{Ca}_{\mathrm{v}} 3.2$ in edema and inflammatory process observed in our models.

Our study has certain limitations. First, although the spinal and peripheral location of $\mathrm{Ca}_{\mathrm{v}} 3.2$ channels was shown to be involved in inflammatory pain, a supraspinal contribution cannot be ruled out. Indeed, $\mathrm{Ca}_{\mathrm{v}} 3.2$ channels are expressed in the brain (Bernal Sierra et al., 2017) and intracerebroventricular injection of TTAA2 induced antinociception in the formalin test in mice (Kerckhove et al., 2014). However, the fact that ablation of $\mathrm{Ca}_{\mathrm{v}} 3.2$ channels in C-LTMRs totally suppressed pain-like symptoms in our inflammatory models detracts from this hypothesis. In addition, we cannot definitively conclude that the reduced activation and proliferation of macrophages and $\mathrm{CD} 4^{+} \mathrm{T}$ cells that were proposed to explain the anti-edematous effect of $\mathrm{Ca}_{\mathrm{v}} 3.2$ inhibition are the only processes involved. It is possible that a default in the fetal development of the hematopoietic lineage in $\mathrm{Ca}_{\mathrm{v}} 3.2 \mathrm{KO}$ mice or in the recruitment or infiltration process in WT mice also contributes to the observed phenotype. However, after analysis, we observed no significant alteration in the number of the major populations of immune cells in $\mathrm{Ca}_{\mathrm{v}} 3.2 \mathrm{KO}$ mice. Furthermore, other subpopulations of cells involved in inflammation such as monocytes and osteoblasts could account for the action of $\mathrm{Ca}_{\mathrm{v}} 3.2$ channels inhibition. Elucidation of the mechanistic basis of these different questions will require additional experimental approaches, possibly including tissue-specific manipulation of the expression of $\mathrm{Ca}_{\mathrm{v}} 3.2$ channels.

In a clinical perspective, together with reports from the literature, our study supports the need of a more thorough clinical evaluation of T-type channels blockers in the treatment of chronic pain, in order to draw firm conclusions on their potential efficacy, especially in patients with inflammatory pain. The findings of our study would permit a rapid translation in patients by performing a clinical study in patients suffering from inflammatory pain.

\section{LEGENDS OF FIGURES}

Figure 1 Pharmacological evidence of functional involvement of T-type channels in the development and maintenance of inflammation and related pain

The effect of acute TTA-A2 (1 mg/kg, per os ) or vehicle (VEH) treatment was assessed in mice $4 \mathrm{~h}$ after an intraplantar injection of carrageenan (right ) or 7 days after an intra-articular administration of Complete Freund's Adjuvant (CFA, middle ). In the CFA model, the effect of repeated (3 times a day from day 7 to day 14) administrations of TTA-A2 (1 mg/kg, per os ) or VEH was also investigated (left ). In all conditions, mechanical allodynia (A), mechanical hyperalgesia (B ) and paw edema (C) were assessed. Statistical differences were assessed by two-way ANOVA (Time, Treatments) followed by Bonferroni post-hoc test [significant differences between VEH and TTA-A2 group are indicated by asterisks $\left({ }^{*} p<0.05 ;{ }^{* *} p<\right.$ $\left.\left.0.01 ;{ }^{* * *} p<0.001\right)\right]$. Data represent mean \pm SEM.

Figure 2 Genetic evidence for the functional involvement of $\mathrm{Ca}_{\mathrm{v}} 3.2$ channels in the development 


\section{of inflammation and related pain}

$\mathrm{Ca}_{\mathrm{v}} 3.2$ knock out mice $\left(\mathrm{Ca}_{\mathrm{v}} 3.2 \mathrm{KO}\right)$ and their wild type littermates (WT) received an intraplantar administration of carrageenan (right) or an intraarticular injection of CFA (left ). Mechanical allodynia (A ) and hyperalgesia (B ) were assessed by the von Frey test using $0.04 \mathrm{~g}$ and $1.4 \mathrm{~g}$ filaments, respectively. Edema size $(\mathbf{C})$ was measured with a caliper. IL-6 levels in edema (D ) was analyzed by ELISA in supernatant from culture of edema. Statistical differences were assessed by two-way ANOVA (Time, Genotype) followed by Bonferroni post-hoc test [significant differences between $\mathrm{WT}$ and $\mathrm{Ca}_{\mathrm{v}} 3.2 \mathrm{KO}$ group are indicated by asterisks $\left.\left({ }^{*} p<0.05 ;{ }^{* *} p<0.01 ;{ }^{* *} p<0.001\right)\right]$. Statistical differences for IL-6 levels in edema were assessed by Mann-Whitney test [significant differences between WT and $\mathrm{Ca}_{\mathrm{v}} 3.2 \mathrm{KO}$ group are indicated by asterisks $\left.\left({ }^{*} p<0.05 ;{ }^{* * *} p<0.001\right)\right]$. Data represent mean \pm SEM.

\section{Figure 3 Contribution of peripheral-located $\mathrm{Ca}_{\mathrm{v}} 3.2$ channels in inflammatory pain}

Mechanical allodynia (left ) and mechanical hyperalgesia (right) were assessed in $\mathrm{Ca}_{\mathrm{v}} 3.2^{\mathrm{Nav} 1.8} \mathrm{cKO}$ mice and their control littermates $\left(\mathrm{Ca}_{\mathrm{v}} 3.2^{\mathrm{GFP}-\text { flox } \mathrm{KI})}\right.$ receiving either an intraplantar injection of carrageenan (A ) or intraarticular CFA (B ). Mice were submitted to the von Frey test to assess mechanical allodynia (left ) and hyperalgesia (right). Statistical differences were assessed by two-way ANOVA (Time, Genotype or Treatments) followed by Bonferroni post-hoc test [significant differences between $\mathrm{Ca}_{\mathrm{v}} 3.2^{\mathrm{Nav} 1.8} \mathrm{cKO}$ and $\mathrm{Ca}_{\mathrm{v}} 3.2^{\text {GFP-flox }} \mathrm{KI}$ group are indicated by asterisks $\left.\left({ }^{*} p<0.05 ;{ }^{* *} p<0.01 ;{ }^{* * *} p<0.001\right)\right]$. Data represent mean \pm SEM.

Figure 4 Contribution of both peripheral- and spinal-located $\mathrm{Ca}_{\mathrm{v}} 3.2$ channels in inflammatory pain

The effect of a systemic administration of ABT-639 (10, 30 or $100 \mathrm{mg} / \mathrm{kg}$, i.p., C, D ) or intraplantar injection of ABT-639 $(2.5 \mu \mathrm{l}$ in $20 \mu \mathrm{l}, \mathbf{E})$ or an intrathecal injection of ABT-639 $(10 \mu \mathrm{g}$ in $5 \mu \mathrm{l}, \mathbf{F})$ or their respective vehicles (VEH) were evaluated in the carrageenan (A , C ) and CFA (D-F ) models. In all conditions, mice were submitted to the von Frey test to assess mechanical allodynia (left ) and hyperalgesia (right ). Statistical differences were assessed by two-way ANOVA (Time, Genotype or Treatments) followed by Bonferroni post-hoc test [significant differences between VEH and ABT-639 group are indicated by asterisks $\left.\left({ }^{*} p<0.05 ;{ }^{* *} p<0.01 ;{ }^{* * *} p<0.001\right)\right]$. Data represent mean \pm SEM.

Figure 5 Anti-inflammatory effect of $\mathrm{Ca}_{\mathrm{v}} 3.2$ channels inhibition is mediated by immune cells

Edema development after carrageenan injection in $\mathrm{Ca}_{\mathrm{v}} 3.2^{\mathrm{Nav} 1.8} \mathrm{cKO}$ and $\mathrm{Ca}_{\mathrm{v}} 3.2^{\mathrm{GFP}-f l o x} \mathrm{KI}$ mice (A ). (B ) Representation of chimeric mice generation. WT and $\mathrm{Ca}_{\mathrm{v}} 3.2 \mathrm{KO}$ mice (recipients) are irradiated. In irradiated mice, bone marrow cells retrieved from un-irradiated $\mathrm{WT}$ or $\mathrm{Ca}_{\mathrm{v}} 3.2 \mathrm{KO}$ mice (donors) were transplanted by intravenous injection. Four experimental groups were obtained: WT mice transplanted with bone marrow cells from $\mathrm{Ca}_{\mathrm{v}} 3.2 \mathrm{KO} ; \mathrm{Ca}_{\mathrm{v}} 3.2 \mathrm{KO}$ mice transferred with bone marrow cells from WT donors; WT mice transferred with bone marrow cells from WT donors; and $\mathrm{Ca}_{\mathrm{v}} 3.2 \mathrm{KO}$ mice transferred with bone marrow cells from KO donors. Edema development (C) and IL-6 production (D) in chimeric mice 4 hours after injection of carrageenan, 8 weeks after the bone marrow transplantation. (E ) BMDM and CD4 ${ }^{+} \mathrm{T}$ cells, obtained from WT and $\mathrm{Ca}_{\mathrm{v}} 3.2^{\mathrm{GFP}-f l o x} \mathrm{KI}$ mice stained with antibody anti-eGFP or isotype control revealing the expression of $\mathrm{Ca}_{\mathrm{v}} 3.2$ in these cells.B was analyzed by one-way ANOVA followed by Bonferroni posthoc test: no significant differences were found. For other graphs a one-way ANOVA followed by Bonferroni post-hoc test were performed $\left({ }^{*} p<0.05 ;{ }^{* *} p<0.01 ;{ }^{* * *} p<0.001\right)$. Data represent mean \pm SEM.

Figure $6 \mathrm{Ca}_{\mathrm{v}} 3.2$ channels are involved in the activation/proliferation of macrophages and $\mathrm{T}$ CD4 ${ }^{+}$lymphocytes

Immunohistochemistry of BMDM (actin [phalloidin toxin] = red) and nucleus (DAPI= blue)) from WT and $\mathrm{Ca}_{\mathrm{v}} 3.2 \mathrm{KO}$ mice (A ). BMDM area (B, left ) and IL-6 production in supernatant (B, right ). (C ) Representative recording of LPS-induced calcium signals in single WT and $\mathrm{Ca}_{\mathrm{v}} 3.2 \mathrm{KO}$ BMDM (left ) and percentage of BMDM responding to LPS (right ) (515 cells analyzed for WT and 446 for $\mathrm{Ca}_{\mathrm{v}} 3.2 \mathrm{KO} \mathrm{BMDM}$ from 4 different mice/group). 
Flow cytometry analysis of the activation status (CD86 median fluorescence intensity) in macrophages (D, left ), dendritic cells (DC CD11b ${ }^{+}, \mathbf{D}$, middle ) and inflammatory monocytes (D, right ) from spleen of WT and $\mathrm{Ca}_{\mathrm{v}} 3.2 \mathrm{KO}$ mice. (E ) Proliferation capacity of $\mathrm{WT}$ and $\mathrm{Ca}_{\mathrm{v}} 3.2 \mathrm{KO}$ T cells stained with CFSE under CD3/CD28 stimulation for 4 days. Representative flow cytometry data showing CFSE peaks displayed by $\mathrm{CD} 4^{+} \mathrm{T}$ cells $\left(\mathbf{E}\right.$, left ). Quantification of $\mathrm{T} \mathrm{CD} 4^{+}$cells after proliferation (E, middle and right ). B left and right and $\mathbf{E}$ middle were analyzed by one-way ANOVA followed by Bonferroni post-hoc test $\left({ }^{*} p\right.$ $\left.<0.05 ;{ }^{* * *} p<0.001\right)$. Other graphs were analyzed by Mann-Whitney test $\left({ }^{* *} p<0.01 ;{ }^{* * *} p<0.001\right)$. Data represent mean \pm SEM.

\section{REFERENCES}

Berger, N.D., Gadotti, V.M., Petrov, R.R., Chapman, K., Diaz, P., and Zamponi, G.W. (2014). NMP7 inhibits chronic inflammatory and neuropathic pain via block of Cav3.2 T-type calcium channels and activation of CB2 receptors. Mol. Pain $10: 77$.

Bernal Sierra, Y.A., Haseleu, J., Kozlenkov, A., Bégay, V., and Lewin, G.R. (2017). Genetic Tracing of Cav3.2 T-Type Calcium Channel Expression in the Peripheral Nervous System. Front. Mol. Neurosci. 10 : 70.

Bohic, M., Marics, I., Santos, C., Malapert, P., Ben-Arie, N., Salio, C., et al. (2020). Loss of bhlha9 Impairs Thermotaxis and Formalin-Evoked Pain in a Sexually Dimorphic Manner. Cell Rep.30 : 602-610.e6.

Bourinet, E., Alloui, A., Monteil, A., Barrere, C., Couette, B., Poirot, O., et al. (2005). Silencing of the Cav3.2 T-type calcium channel gene in sensory neurons demonstrates its major role in nociception. Embo J24: 315-24.

Bourinet, E., Francois, A., and Laffray, S. (2016). T-type calcium channels in neuropathic pain. Pain 157 Suppl 1 : S15-22.

Boyman, O., Comte, D., and Spertini, F. (2014). Adverse reactions to biologic agents and their medical management. Nat. Rev. Rheumatol.10 : 612-627.

Carbone, E., Giancippoli, A., Marcantoni, A., Guido, D., and Carabelli, V. (2006). A new role for T-type channels in fast 'low-threshold' exocytosis. Cell Calcium $40: 147-154$.

Chen, C.-C., Lamping, K.G., Nuno, D.W., Barresi, R., Prouty, S.J., Lavoie, J.L., et al. (2003). Abnormal coronary function in mice deficient in alpha1H T-type Ca2+ channels. Science 302 : 1416-1418.

Choe, W., Messinger, R.B., Leach, E., Eckle, V.-S., Obradovic, A., Salajegheh, R., et al. (2011). TTA-P2 is a potent and selective blocker of T-type calcium channels in rat sensory neurons and a novel antinociceptive agent. Mol. Pharmacol. 80 : 900-910.

Choi, S., Na, H.S., Kim, J., Lee, J., Lee, S., Kim, D., et al. (2007). Attenuated pain responses in mice lacking $\mathrm{Ca}(\mathrm{V}) 3.2$ T-type channels. Genes Brain Behav. 6 : 425-431.

Curtis, M.J., Alexander, S., Cirino, G., Docherty, J.R., George, C.H., Giembycz, M.A., et al. (2018). Experimental design and analysis and their reporting II: updated and simplified guidance for authors and peer reviewers. Br. J. Pharmacol. 175 : 987-993.

Curtis, M.J., Bond, R.A., Spina, D., Ahluwalia, A., Alexander, S.P.A., Giembycz, M.A., et al. (2015). Experimental design and analysis and their reporting: new guidance for publication in BJP. Br. J. Pharmacol.172 : 3461-3471.

Dalmann, R., Daulhac, L., Antri, M., Eschalier, A., and Mallet, C. (2015). Supra-spinal FAAH is required for the analgesic action of paracetamol in an inflammatory context. Neuropharmacology $91: 63-70$.

Delfini, M.-C., Mantilleri, A., Gaillard, S., Hao, J., Reynders, A., Malapert, P., et al. (2013). TAFA4, a chemokine-like protein, modulates injury-induced mechanical and chemical pain hypersensitivity in mice. Cell Rep. 5 : 378-388. 
Francois, A., Kerckhove, N., Meleine, M., Alloui, A., Barrere, C., Gelot, A., et al. (2013). State-dependent properties of a new T-type calcium channel blocker enhance $\mathrm{Ca}(\mathrm{V}) 3.2$ selectivity and support analgesic effects. Pain 154 : 283-293.

François, A., Schüetter, N., Laffray, S., Sanguesa, J., Pizzoccaro, A., Dubel, S., et al. (2015). The LowThreshold Calcium Channel Cav3.2 Determines Low-Threshold Mechanoreceptor Function. Cell Rep.

García-Caballero, A., Gadotti, V.M., Stemkowski, P., Weiss, N., Souza, I.A., Hodgkinson, V., et al. (2014). The deubiquitinating enzyme USP5 modulates neuropathic and inflammatory pain by enhancing Cav3.2 channel activity. Neuron 83 : 1144-1158.

Graham, G.G., Davies, M.J., Day, R.O., Mohamudally, A., and Scott, K.F. (2013). The modern pharmacology of paracetamol: therapeutic actions, mechanism of action, metabolism, toxicity and recent pharmacological findings. Inflammopharmacology $21: 201-232$.

Hellman, P., and Eriksson, H. (2007). Early activation markers of human peripheral dendritic cells. Hum. Immunol. $68: 324-333$.

Højsted, J., and Sjøgren, P. (2007). Addiction to opioids in chronic pain patients: a literature review. Eur. J. Pain Lond. Engl. 11 : 490-518.

Ioannidis, J.P.A., Karassa, F.B., Druyts, E., Thorlund, K., and Mills, E.J. (2013). Biologic agents in rheumatology: unmet issues after 200 trials and $\$ 200$ billion sales. Nat. Rev. Rheumatol. 9 : 665-673.

Jacus, M.O., Uebele, V.N., Renger, J.J., and Todorovic, S.M. (2012). Presynaptic Cav3.2 channels regulate excitatory neurotransmission in nociceptive dorsal horn neurons. J. Neurosci. Off. J. Soc. Neurosci.32 : 9374-9382.

Jarvis, M.F., Scott, V.E., McGaraughty, S., Chu, K.L., Xu, J., Niforatos, W., et al. (2014). A peripherally acting, selective T-type calcium channel blocker, ABT-639, effectively reduces nociceptive and neuropathic pain in rats. Biochem. Pharmacol. $89: 536-544$.

Kerckhove, N., Boudieu, L., Ourties, G., Bourdier, J., Daulhac, L., Eschalier, A., et al. (2019). Ethosuximide improves chronic pain-induced anxiety- and depression-like behaviors. Eur. Neuropsychopharmacol. J. Eur. Coll. Neuropsychopharmacol. $29: 1419-1432$.

Kerckhove, N., Mallet, C., François, A., Boudes, M., Chemin, J., Voets, T., et al. (2014). Ca(v)3.2 calcium channels: the key protagonist in the supraspinal effect of paracetamol. Pain $155: 764-772$.

Lee, I.O., and Jeong, Y.S. (2002). Effects of different concentrations of formalin on paw edema and pain behaviors in rats. J. Korean Med. Sci.17 : 81-85.

Lee, J., Kim, D., and Shin, H.-S. (2004). Lack of delta waves and sleep disturbances during non-rapid eye movement sleep in mice lacking alpha1G-subunit of T-type calcium channels. Proc. Natl. Acad. Sci. U. S. A. $101: 18195-18199$.

Matsunami, M., Miki, T., Nishiura, K., Hayashi, Y., Okawa, Y., Nishikawa, H., et al. (2012). Involvement of the endogenous hydrogen sulfide/Ca(v) 3.2 T-type Ca2+ channel pathway in cystitis-related bladder pain in mice. Br. J. Pharmacol. 167: 917-928.

Percie du Sert, N., Ahluwalia, A., Alam, S., Avey, M.T., Baker, M., Browne, W.J., et al. (2020). Reporting animal research: Explanation and elaboration for the ARRIVE guidelines 2.0. PLoS Biol. 18 : e3000411.

Perez-Reyes, E. (2003). Molecular physiology of low-voltage-activated t-type calcium channels. Physiol. Rev. $83: 117-161$.

Picard, E., Carvalho, F.A., Agosti, F., Bourinet, E., Ardid, D., Eschalier, A., et al. (2019). Inhibition of Cav 3.2 calcium channels: A new target for colonic hypersensitivity associated with low-grade inflammation. Br. J. Pharmacol. 176 : 950-963. 
Pinho-Ribeiro, F.A., Verri, W.A., and Chiu, I.M. (2017). Nociceptor Sensory Neuron-Immune Interactions in Pain and Inflammation. Trends Immunol. $38: 5-19$.

Reynders, A., Mantilleri, A., Malapert, P., Rialle, S., Nidelet, S., Laffray, S., et al. (2015). Transcriptional Profiling of Cutaneous MRGPRD Free Nerve Endings and C-LTMRs. Cell Rep. 10 : 1007-1019.

Roda, G., Jharap, B., Neeraj, N., and Colombel, J.-F. (2016). Loss of Response to Anti-TNFs: Definition, Epidemiology, and Management. Clin. Transl. Gastroenterol. 7 : e135.

Samour, M.S., Nagi, S.S., and Mahns, D.A. (2015). Cav3.2-expressing low-threshold C fibres in human hairy skin contribute to cold allodynia-a non-TRPV1- and non-TRPM8-dependent phenomenon. Pain 156 : $1566-1575$.

Scanzi, J., Accarie, A., Muller, E., Pereira, B., Aissouni, Y., Goutte, M., et al. (2016). Colonic overexpression of the T-type calcium channel Cav 3.2 in a mouse model of visceral hypersensitivity and in irritable bowel syndrome patients. Neurogastroenterol. Motil. Off. J. Eur. Gastrointest. Motil. Soc. 28 : 1632-1640.

Seal, R.P., Wang, X., Guan, Y., Raja, S.N., Woodbury, C.J., Basbaum, A.I., et al. (2009). Injury-induced mechanical hypersensitivity requires C-low threshold mechanoreceptors. Nature 462 : 651-5.

Silva, J.A.P. da, Ramiro, S., Pedro, S., Rodrigues, A., Vasconcelos, J.C., and Benito-Garcia, E. (2010). Patients- and physicians- priorities for improvement. The case of rheumatic diseases. Acta Reumatol. Port.35 : 192-199.

Smith, M.D., Woodhead, J.H., Handy, L.J., Pruess, T.H., Vanegas, F., Grussendorf, E., et al. (2017). Preclinical Comparison of Mechanistically Different Antiseizure, Antinociceptive, and/or Antidepressant Drugs in a Battery of Rodent Models of Nociceptive and Neuropathic Pain. Neurochem. Res. 42 : 1995-2010.

Smolen, J.S., Landewé, R., Bijlsma, J., Burmester, G., Chatzidionysiou, K., Dougados, M., et al. (2017). EULAR recommendations for the management of rheumatoid arthritis with synthetic and biological diseasemodifying antirheumatic drugs: 2016 update. Ann. Rheum. Dis. 76 : 960-977.

Smolen, J.S., Strand, V., Koenig, A.S., Szumski, A., Kotak, S., and Jones, T.V. (2016). Discordance between patient and physician assessments of global disease activity in rheumatoid arthritis and association with work productivity. Arthritis Res. Ther. $18: 114$.

Snutch, T.P., and Zamponi, G.W. (2018). Recent advances in the development of T-type calcium channel blockers for pain intervention. Br. J. Pharmacol. 175 : 2375-2383.

Stirling, L.C., Forlani, G., Baker, M.D., Wood, J.N., Matthews, E.A., Dickenson, A.H., et al. (2005). Nociceptor-specific gene deletion using heterozygous NaV1.8-Cre recombinase mice. Pain 113:27-36.

Sturgeon, J.A., Finan, P.H., and Zautra, A.J. (2016). Affective disturbance in rheumatoid arthritis: psychological and disease-related pathways. Nat. Rev. Rheumatol. 12 : 532-542.

Taylor, P., Manger, B., Alvaro-Gracia, J., Johnstone, R., Gomez-Reino, J., Eberhardt, E., et al. (2010). Patient perceptions concerning pain management in the treatment of rheumatoid arthritis. J. Int. Med. Res.38: 1213-1224.

Todorovic, S.M., and Jevtovic-Todorovic, V. (2011). T-type voltage-gated calcium channels as targets for the development of novel pain therapies. Br. J. Pharmacol. 163 : 484-495.

Urien, L., Gaillard, S., Lo Re, L., Malapert, P., Bohic, M., Reynders, A., et al. (2017). Genetic ablation of GINIP-expressing primary sensory neurons strongly impairs Formalin-evoked pain. Sci. Rep. $7: 43493$.

Walsh, D.A., and McWilliams, D.F. (2014). Mechanisms, impact and management of pain in rheumatoid arthritis. Nat. Rev. Rheumatol.10 : 581-592.

Weyand, C.M., and Goronzy, J.J. (2021). The immunology of rheumatoid arthritis. Nat. Immunol. 22 : $10-18$. 
Xanthos, D.N., and Sandkühler, J. (2014). Neurogenic neuroinflammation: inflammatory CNS reactions in response to neuronal activity. Nat. Rev. Neurosci. $15: 43-53$.

Zhou, X., Yang, W., and Li, J. (2006). Ca2+- and protein kinase C-dependent signaling pathway for nuclear factor-kappaB activation, inducible nitric-oxide synthase expression, and tumor necrosis factor-alpha production in lipopolysaccharide-stimulated rat peritoneal macrophages. J. Biol. Chem. 281 : 31337-31347.

Ziegler, D., Duan, W.R., An, G., Thomas, J.W., and Nothaft, W. (2015). A randomized double-blind, placebo-, and active-controlled study of T-type calcium channel blocker ABT-639 in patients with diabetic peripheral neuropathic pain. Pain 156 : 2013-2020.

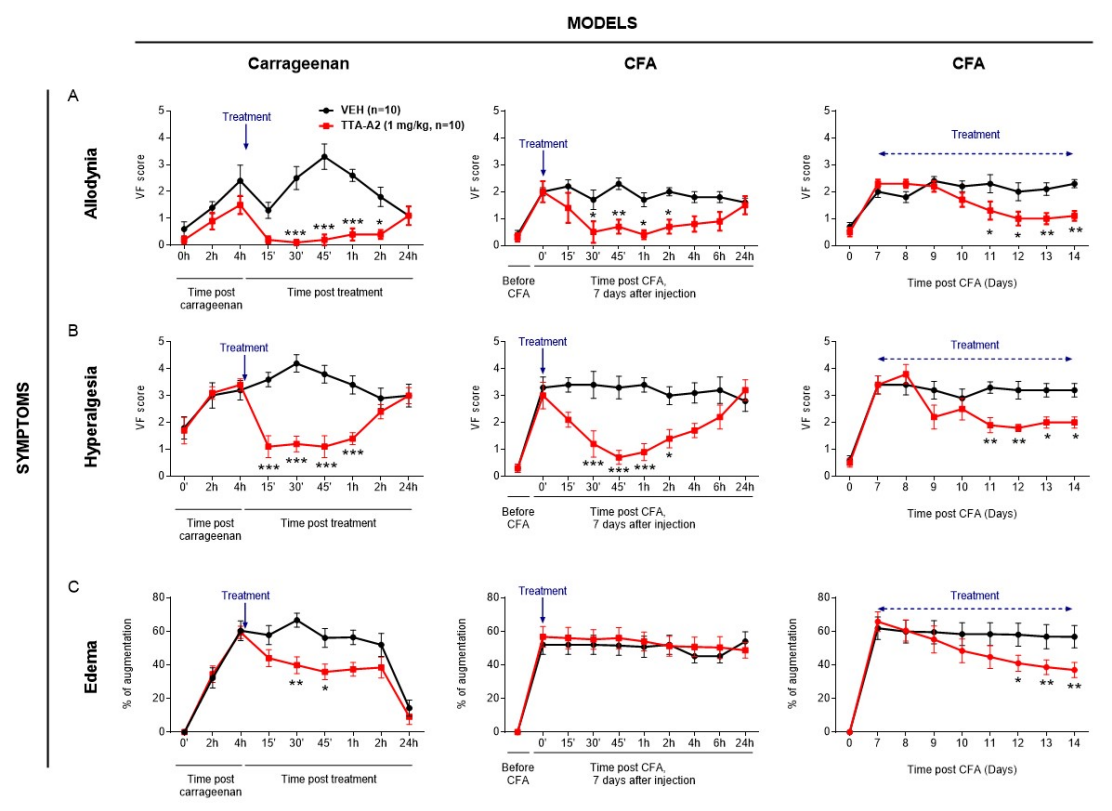




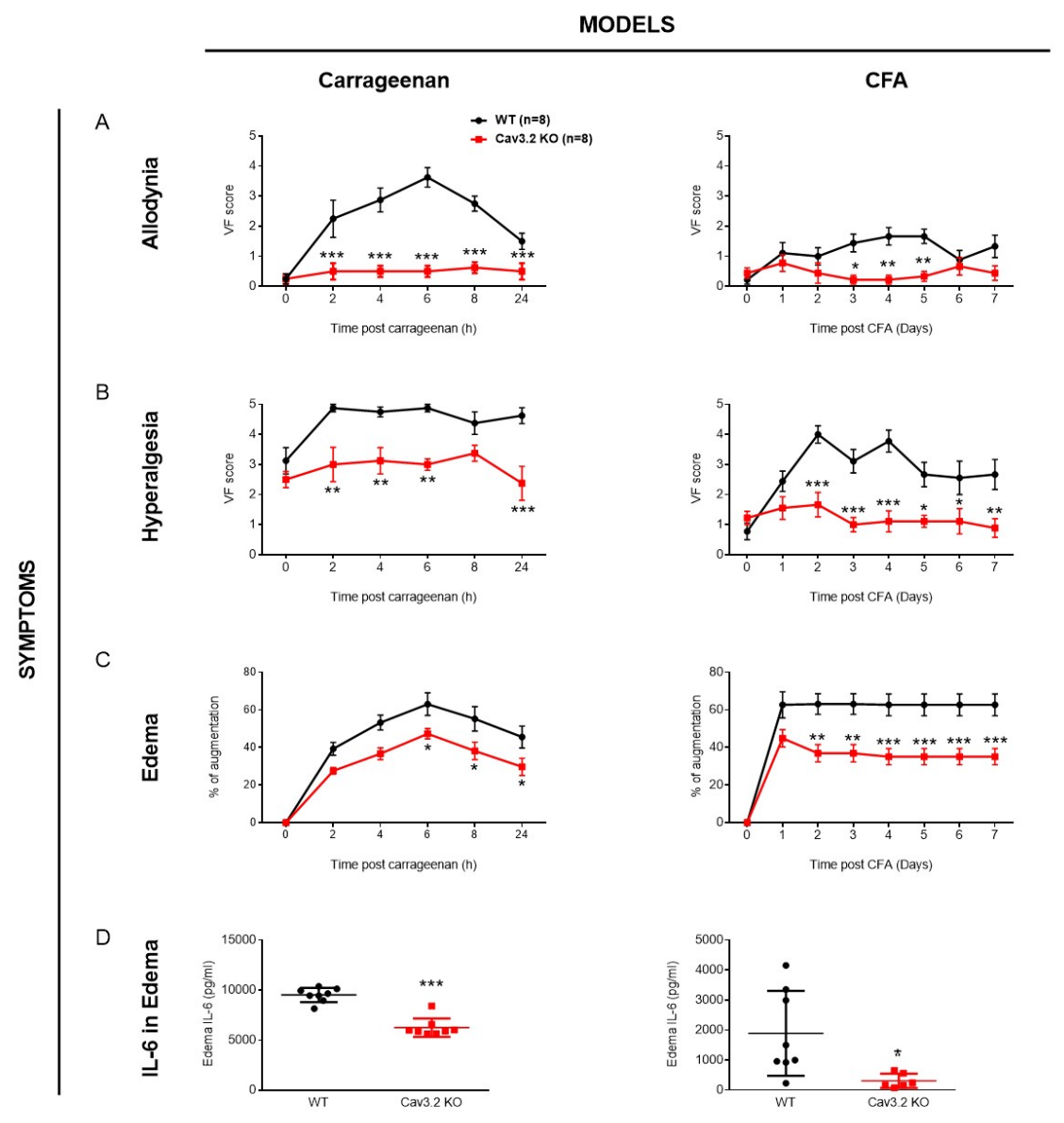

A

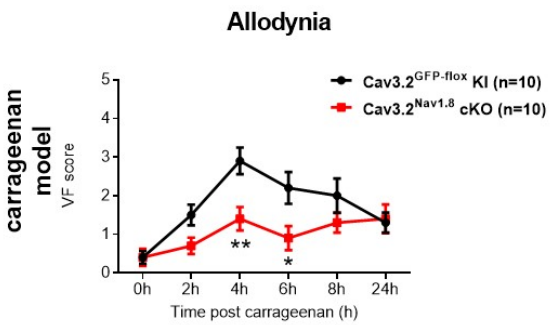

Hyperalgesia

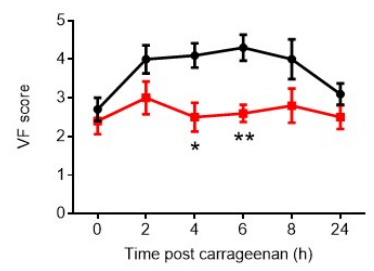

B
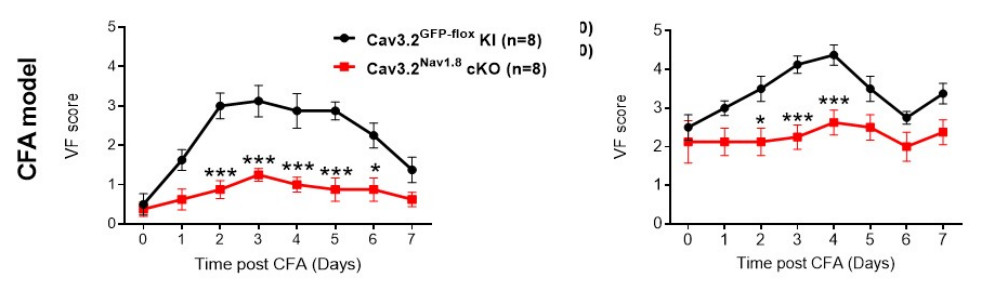
A

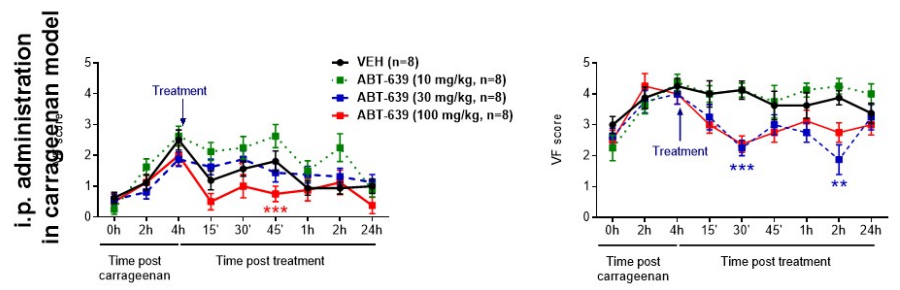

B
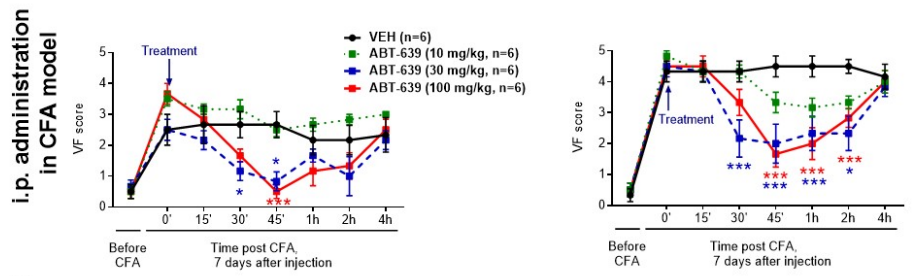

c
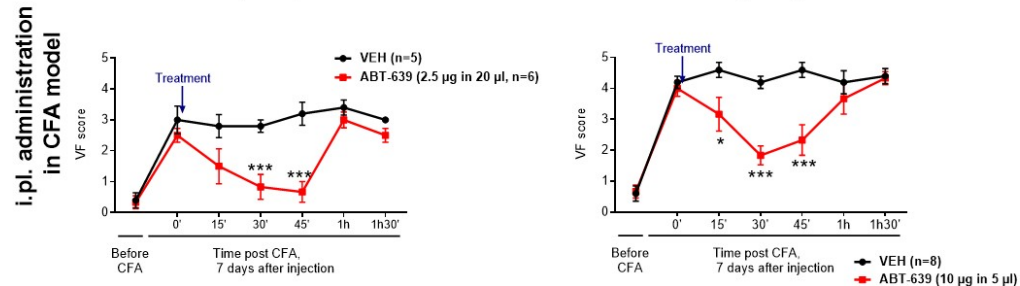

D
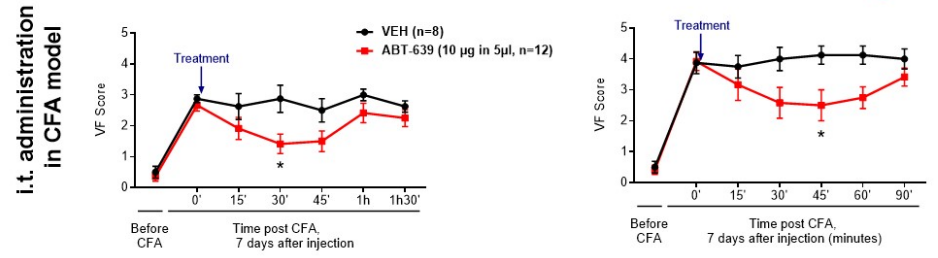


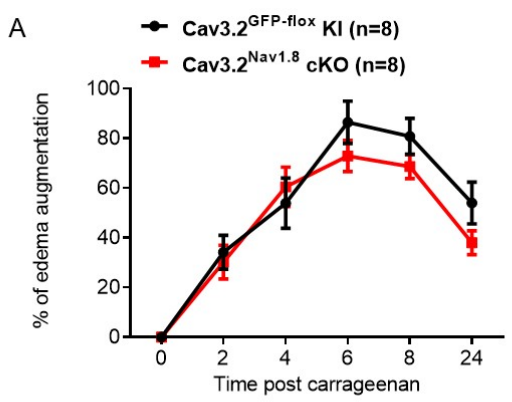

B

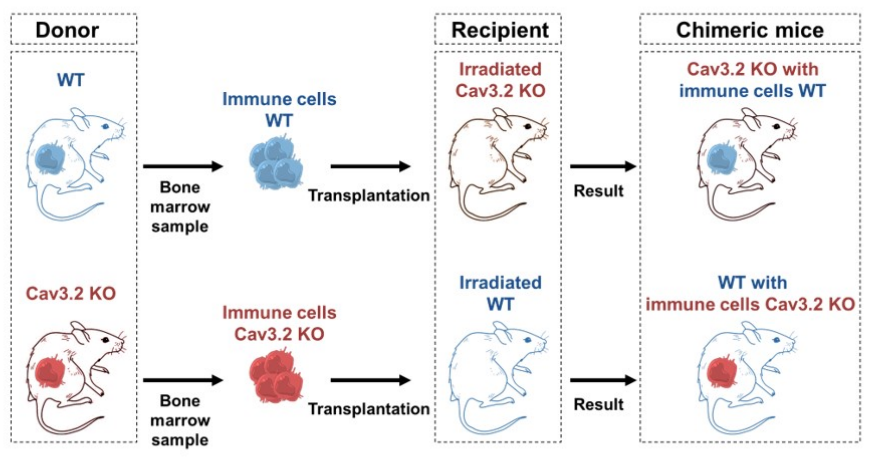

C
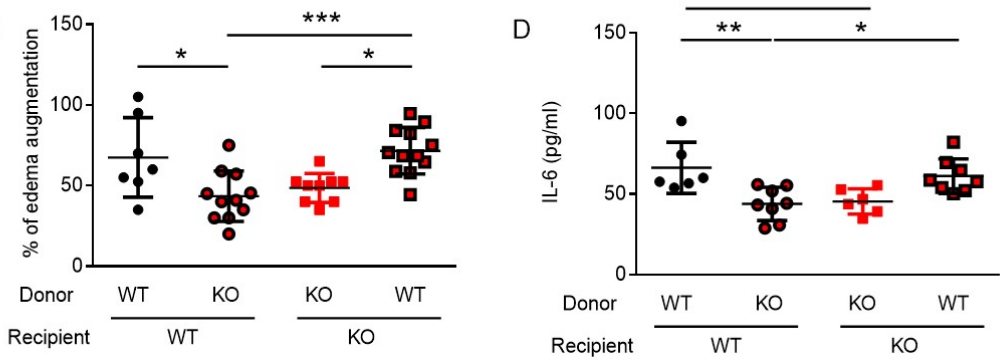

E

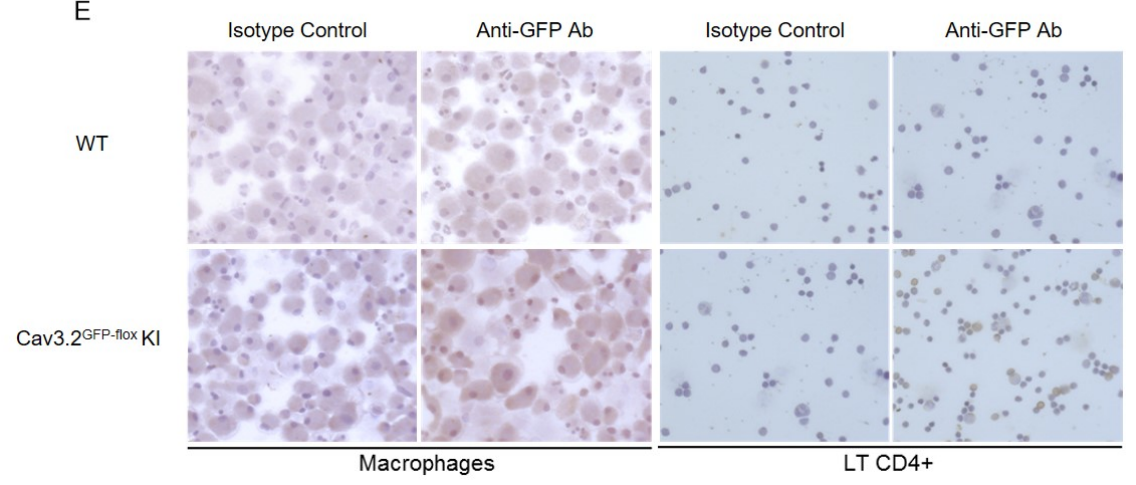



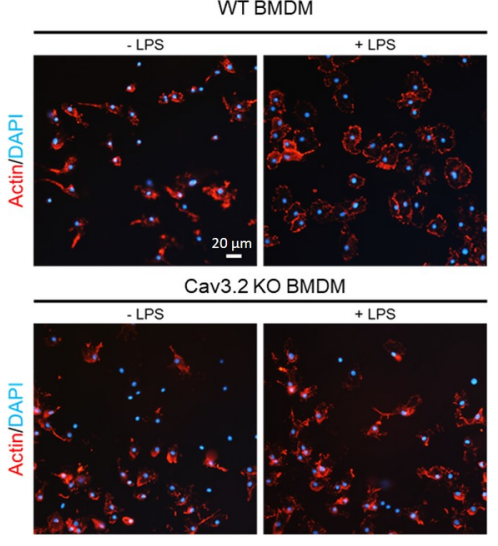

WT BMDM
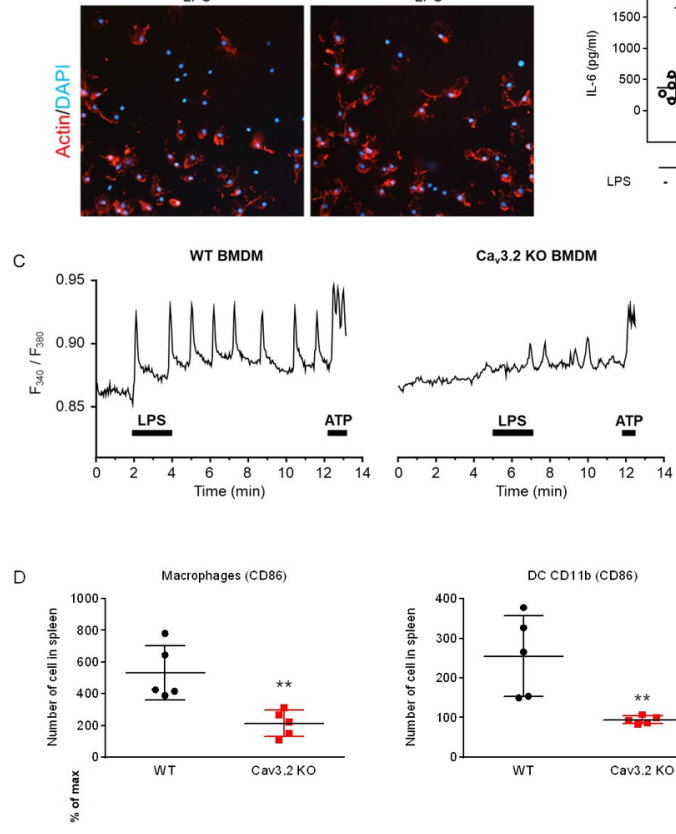

E

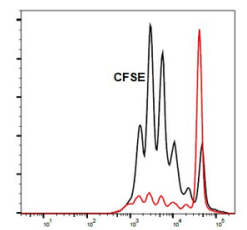

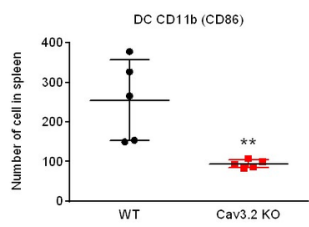
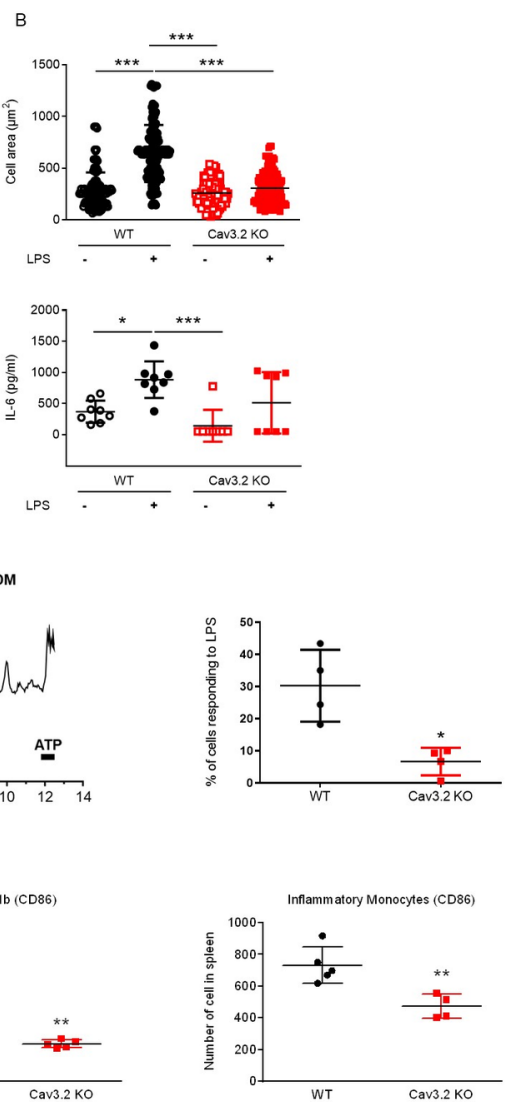

- $\quad w T(n=4)$

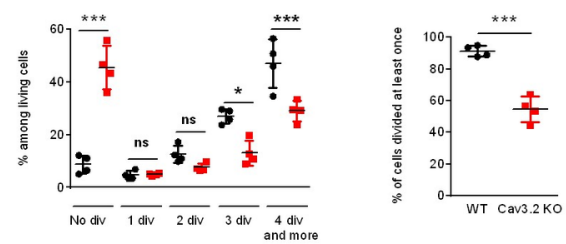

